\title{
Family Nutrition Improvement Efforts Through Nutrition Management of Pokea Clam Based on Environmental Health
}

\author{
I Putu Sudayasa ${ }^{*}$, Hartati $^{2}$, Bahtiar $^{3}$ \\ ${ }^{1.2}$ Faculty of Medicine, Halu Oleo University. Jl. HEA Mokodompit, Andonouhu, Kendari 93232, \\ Indonesia \\ ${ }^{3}$ Faculty of Fisheries and Marine Sciences, Halu Oleo University, Jl. HEA Mokodompit, Andonouhu, \\ Kendari 93232, Indonesia \\ *dr.putusudayasa@uho.ac.id
}

Submission: 10 December 2018; Acceptance: 26 July 2019

\begin{abstract}
Keywords:
Abstract The coastal communities of the Pohara river, Sampara Subdistrict, where the

Sampara sub-

district, pokea habitat for endemic pokea clam growth, has a habit of consuming pokea clam meat clam, Pohara coastal, consumption pattern, nutritional which can affect the nutritional status of the family. Pokea clam meat (Batissa violacea celebensis von Marten 1897) contains fatty acids, which can reduce the risk of cardiovascular disease. The purpose of this community service, to identify patterns of consumption of pokea clam and nutritional status. The method used through interviews, counseling and examination of nutritional status. The number of status respondents identified was 72 respondents. Data were collected by questionnaire regarding the consumption pattern of pokea clam, measurement of height, weight and waist circumference. The results of the identification of consumption patterns of pokea clam meat showed $58 \%$ of respondents, consuming average pokea clam 1-3 times a day. As many as $78 \%$, processing directly the pokea clam meat. The types of preparations consumed are pokea satay (39\%) and boiled pokea (8\%). The results of examination of Body Mass Index (BMI) obtained 50.0\% normal nutritional status, $16.7 \%$ excess and $30.6 \%$ obesity. Waist circumference measurement results, $47.2 \%$ are normal, and $52.8 \%$ are not normal. Integrated and sustainable health promotion, need to improve the nutritional status of coastal communities.
\end{abstract}

\section{INTRODUCTION}

Characteristics of coastal communities in the Pohara river, Sampara Subdistrict, as an endemic area for pokea clam, have a habit of consuming pokea clam meat, which has the potential to increase the nutritional status of their families. The nutritional potential of pokea clam meat (Batissa violacea celebensis von Marten, 1897) contains fatty acids, which can reduce the risk of cardiovascular disease. Types of cardiovascular disease that often occur include hypertension and coronary heart disease. The proportion of family 
nutrition health problems varies greatly according to social conditions, demographic factors and geographical area, so that these conditions will determine the strategy for handling public health problems, especially through dietary arrangements. Healthy, nutritious and balanced consumption patterns can prevent the occurrence of heart disease and blood vessels (Dinkes Sultra, 2018).

Considering the potential of biological resources of Pokea clam, which are found on the Pohara river coast, which are related to environmental health issues in the region, there is still a lack of human resources in the field of nutritional health, still a large number of poor families, and the need for a community health service approach comprehensive, especially about the health of the residential environment, and efforts to manage nutrition of the Pokea clam, for family nutrition health. The level of public knowledge that is still lacking about the goals and benefits of managing the nutritional content of Pokea clam, to improve family nutrition health. The limited resources in the field of family nutrition health to conduct nutritional status checks, nutrition health education, environmental health education and nutrition management of pokea clam, to the coastal communities of Pohara (BPS Konawe, 2017). The community service activities carried out by the lecturer team of the Faculty of Medicine of the University of Halu Oleo, together with students and health workers at the Sampara health center, are one of the real manifestations of this. The purpose of this activity was to conduct counseling on family nutrition issues, detect family nutritional status and assess the consumption pattern of pokea clam in coastal communities. 


\section{LITERATURE OR CONCEPTUAL REVIEW}

\subsection{Family Nutrition Services}

The health service program has been proclaimed by the government, in order to create a better public health degree, among others in the form of health financing subsidies, increasing human resources in the health sector, increasing drug and medical supplies, community empowerment, and improving health management. The program aims to increase the affordability or accessibility of the population, especially the poor or disadvantaged communities, in the coverage of family nutrition health services (Kemenkes, 2014).

The health of family nutrition is a fundamental right for everyone regardless of the economic and social status of the community itself. A good family nutrition condition will determine the health status of the community. The cause of the emergence of nutritional problems is multifactorial so that the response requires approaches from various sectors. In reality, improving family nutrition health, especially for coastal communities, faces many obstacles. Health services have not been able to reach all citizens, especially for pre-prosperous family communities. This situation can be anticipated by doing health services based on the family nutrition approach, so that each family member can strive for clean and healthy living, starting from his family environment (Kemenkes, 2019).

\subsection{Nutrition Counseling and Environmental Health}

The definition of health education is the same as public health education, which is an activity or business to convey health messages to the community, groups or individuals. With the hope that with the existence of the message or individuals can obtain knowledge 
about better health. Finally, this knowledge is expected to affect on behavior. Through health education efforts can have an affect on changes in target behavior.

Health education is also a process, where the process has input (input) and output (output). In a process of health education that leads to the achievement of educational goals, behavior change is influenced by many factors. Factors that influence an educational process in addition to its input are also material methods or messages, educators or officers who do it, and educational aids or teaching aids. To achieve an optimal result, these factors must cooperate harmoniously. This means that for certain inputs (educational goals), they must also use certain methods, the material must also be adapted to the target, as well as educational aids adapted. For group goals, the method must be different from the mass target and individual goals. For mass targets, they must be different from individual goals (Notoatmodjo, 2011).

\subsection{Examination of Family Nutrition Status}

Nutrition is a process of using food consumed normally through the process of digestion, absorption, transportation, storage, metabolism, and expenditure of substances that are not used to maintain life, growth and normal function of organs, and produce energy. Nutritional status is the body's condition as a result of food consumption and substance use. Optimal nutritional status according to is a balance between nutrient intake and nutrient requirements (Supariasa, 2017).

Assessment of nutritional status (ANS) can be obtained from data that has been interpreted using various methods. Assessment of nutritional status can provide an overview of the methods used to assess nutritional status, provide an explanation of the advantages and disadvantages of existing methods, and provide a brief overview to assess 
nutritional status which includes data collection, planning, and implementation. The method in ANS can be a direct, indirect, and evaluation method by looking at ecological variables (Wiyono et al. 2016).

The method directly includes an assessment by looking at clinical signs, laboratory tests, physical methods, and anthropometry. Indirect methods can be done by looking at health statistics. Assessment by looking at ecological variables is needed to determine the causes of malnutrition such as by looking at socio-economic factors, factors related to food, health aspects, demographic factors, politics and policy, culture, geography, and climate. Anthropometry is often used as an indicator to determine nutritional status. When viewed from a nutritional perspective, nutritional anthropometry is related to various measurements of body dimensions and composition from various age levels and nutritional levels. Anthropometry as an indicator of nutritional status can be done by measuring several parameters, as a single measure of the human body, including: age, body weight, height, upper arm circumference, head circumference, chest circumference, hip circumference, and fat thickness under the skin Anthropometric index values according to the limits, can be used as indicators of nutritional status (Supariasa et al., 2017). Assessment of nutritional status can also be done indirectly, namely by consumption surveys. Frequent consumption surveys for households and individuals include using food frequency questionaire (FFQ), and recall of 24-hour food. In FFQ the types of food are recorded, the frequency of use of food ingredients and the amount of food used. A 24-hour food recall is to recall foods that have been consumed 24 hours a day before. Through the recall of 24-hour food, it can be seen the amount of food consumed and the adequacy of one's nutrition. 


\subsection{Pokea Clam Nutrition Management}

Clam are in the Mollusca phylum, besides having a soft body, the clam also has a shell called the "valve", so that with a bilateral symmetrical size and consisting of two clams, the clam is called bivalves. In the dorsal part, there is umbo which is the center of the growth of the shell. While connecting the two clam, the ligament is in the dorsal position behind the apex. Pokea clam (B. violacea celebensis von Martens, 1897) are dark brown to blackish purple. The length of the pokea shell varies, which averages around 3.19-4.26 cm (Bahtiar, 2005).

The results of the identification of the active compounds from the crude extract of pokea clam showed that the crude extract of dried pokea clam in the non-polar fraction (hexane) contained almost all the active compounds analyzed, except for peptide compounds. In the semi-polar fraction (ethyl acetate) no saponin, carbohydrate, peptide, and free amino acid compounds are found. While in the polar fraction (methanol), only phenol and peptide compounds are not identified. Bioactive components contained in crude extracts, such as alkaloids, steroids, saponins, phenols, free amino acids, and carbohydrates are thought to act as antioxidants (Yenny, 2012).

Natural steroids come from various chemical transformations of two triterpenes namely lanosterol and cycloartenol. Steroid compounds can be used as basic ingredients for making drugs. Some steroids such as fukosterol isolated from marine biological resources are nontoxic and have the effect of lowering blood cholesterol and promoting antidiabetic activity. Steroids also have an increase in body stamina (aphrodisiac) and anti-inflammatory effects. Triterpenoid compounds and steroid saponins have antiinflammatory, analgesic, and cytotoxic effects. Saponin has also been known to have 
activity in stimulating apoptosis, which is one type of programmed cell death and is beneficial for the body (Yenny, 2011).

\section{RESEARCH DESIGN}

The series of activities were held in October-November 2018. Family nutrition health service activities carried out in the coastal area of the Pohara river, which is the working area of the Sampara Health Center, Sampara Subdistrict, Konawe District. The peak of the service was held on Friday, November 16, 2018, at 8:00 a.m. to 12:00 a.m. in Andepali Village, located in the coastal area of the Pohara River, Sampara Subdistrict, Konawe Regency.

The technique for implementing this activity is by gathering respondents or service targets at the meeting hall. Then continued with health counseling on nutrition issues and management of pokea clam meat, conducting interviews about the consumption of pokea clam with a questionnaire instrument, checking the nutritional status of the community, which was carried out with health workers from the Sampara Health Center. The collected data is processed in the frequency distribution table and explained in an explorative narrative, according to the problems in the Sampara Subdistrict.

\section{RESULTS}

The community service activities held in Andelapi Village, Sampara District, Konawe District, were centered at Andelapi Village Hall, Jl. Andelapi-Pohara-Sampara axis. Halu Oleo University Faculty of Medicine lecturer service team, in collaboration with the village head, sub-district head, Sampara health center head and Konawe health office, to coordinate the target of those who cannot afford basic health services that have been 
prepared, including health education, measuring nutritional status and assessment on the nutrition management of pokea clam.

\subsection{Extension of Nutrition Utilization of Pokea Clam}

As many as 72 respondents, it was noted that their daily habits in consuming pokea clam were asked. Because the geographical location is near the Konaweha river flow, Pohara, which is known to be the place for catching and processing pokea clam, as a food source.

\section{Table 1. Characteristics of Community Service Respondents}

\begin{tabular}{lcc}
\hline \multicolumn{1}{c}{ Informant Characteristics $(\mathbf{n = 7 2})$} & $\mathbf{f}$ & $\mathbf{\%}$ \\
\hline 1. Gender & 21 & 29,2 \\
a. Male & 51 & 70,8 \\
b. Female & & \\
\hline 2. Age (Years) & 25 & 34,7 \\
a. $15-40$ & 43 & 59,7 \\
b. $41-60$ & 4 & 5,6 \\
c. > 60 & & \\
\hline 3. Occupation & 8 & 11,1 \\
a. Farmer & 47 & 65,3 \\
b. Housewives & 17 & 23,6 \\
c. Employement & & \\
\hline 4. Tribes & 70 & 97,2 \\
a. Tolaki & 2 & 2,8 \\
b. Muna & &
\end{tabular}

Source : Primary Data (2018)

Based on the tabulation of the characteristics respondents, there were $70.8 \%$ female respondents, 59.7\% were 41-60 years old, $65.3 \%$ were housewives, and 97.2\% Tolaki tribe.

\subsection{Measurement of Nutrition Status of the Sampara Coastal Community}

Recapitulation of data in Table 2, results of measurements of body mass index (BMI) and waist circumference, to determine nutritional status, to 72 respondents. 
Table 2. Results of examination of Nutrition Status of Sampara Coastal Community

\begin{tabular}{llcc}
\hline \multicolumn{2}{l}{ A. Body Mass Index $(\mathbf{B M I})$} & f & \% \\
\hline 1. Thin & $(<18,5 \mathrm{~kg} / \mathrm{m} 2)$ & 2 & 2,8 \\
2. Normal & $(18,5-25,0 \mathrm{~kg} / \mathrm{m} 2)$ & 36 & 50,0 \\
3. Overweight & $(25,0-27,0 \mathrm{~kg} / \mathrm{m} 2)$ & 12 & 16,7 \\
4. Obesity $\quad(<27,0 \mathrm{~kg} / \mathrm{m} 2)$ & 22 & 30,6
\end{tabular}

\section{B. Waist Circumference}

1. Normal

34

47,2

2. Not Normal

38

52,8

Source : Primary Data (2018)

The data in Table 2 shows $50 \%$ of the nutritional status of coastal communities, as service respondents, the criteria are normal, but there are still 50\% whose nutritional status is thin, overweight and obesity.

\subsection{Nutrition Management of Pokea Clam}

The results of the recapitulation of the data in Table 3 (Appendix). concerning the consumption pattern of pokea clam, indicate a variation in the number, frequency, type of processing, processing method, type of processing, and complementary foods.

\section{DISCUSSION}

\subsection{Extension of Nutrition Utilization of Pokea Clam}

The target of the free basic medical service activities is poor people from Andelapi Village and around Sampara District, Konawe Regency. The preparation and implementation of this activity also involved the participation of UHO medical students, which greatly helped smooth the implementation of services. Health education activities, basic 
laboratory services are carried out at 08.00 - 12.00 local time. Health counseling was delivered about the nutrition management of the pokea clam, delivered by Mr. Bahtiar, research lecturer, pokea clam ecologist, member of the community service team of the Faculty of Fisheries and Marine Sciences (FPIK) UHO. There were 91 community members, 9 officers and 25 students listening to the counseling. On that occasion, it was also given time to discuss questions and answers with the community. The topic of discussion revolves around the issue of managing nutrition for pokea clam and other health benefits

As many as 72 respondents, it was noted that their daily habits in consuming pokea clam were asked. Because the geographical location of Andelapi Village is near the Konaweha river flow, Pohara, which is known to be the place for catching and processing pokea clam, as a food source.

\subsection{Measurement of Nutrition Status of the Sampara Coastal Community}

While the recapitulation of data in Table 2, the results of body mass index (BMI) measurements and waist circumference, to find out nutritional status, to 72 respondents, showed that the results of body mass index (BMI) examination obtained $50.0 \%$ of respondents with normal nutritional status, while $16,7 \%$ of excess respondents and $30.6 \%$ of obesity. While the results of waist circumference measurements, 47.2\% Normal respondents, and $52.8 \%$ of respondents Not Normal.

The data in Table 2 shows $50 \%$ of the nutritional status of the coastal community of Sampara, as a service informant, the criteria are normal, but there are $50 \%$ whose nutritional status is thin, overweight and obese. This situation requires further intervention in the process of vigilance against, various risks of cardiovascular disease, which can be 
influenced by the state of nutritional status. The intervention model given can be directly or indirectly, according to the specific characteristics of the coastal communities of the Pohara river, especially those who have used the pokea clam properly and correctly, as a food source that has the potential to improve family nutritional status.

\subsection{Nutrition Management of Pokea Clam}

When interviewing as many as $85 \%$ of coastal respondents stated that they often consumed pokea clam in the past three months. A total of $58 \%$ of respondents stated that they consumed 1-3 pokea clam a day. Food for pokea clam is $46 \%$ usually obtained from buying at the market or traveling traders. Where as many as $78 \%$ say processing pokea clam meat directly.

In general, the types of preparations consumed are pokea satay (39\%) and boiled pokea (8\%). As much as $57 \%$, the number of portions of clam consumed $1 / 2-1$ cup. The community manages pokea clam meat, by boiling it as much as $67 \%$, processing it by frying $43 \%$, sauteed $33 \%$. The processing of pokea clam, by boiling it, can affect the nutritional content, especially the composition of fatty acids and cholesterol in pokea clam. (Yenni, et al. 2012). For this reason, the management of pokea clam meat needs to be pursued by preserving the environment, especially in the area of the living habitat of pokea clam along the Pohara river coast, so that the nutritional content can be functioned as an optimal for family health (Yenni, et al, 2011).

Eating companions consumed together with processed pokea clam, $83 \%$ in the form of white rice, only $18 \%$ in the form of rice, a type of snack from rice processed in a mixture with coconut milk, then boiled in a package of banana leaves. While only $7 \%$ consume processed pokea clam, along with gogos, which is a kind of glutinous rice 
processed wrapped in banana leaves, then baked in coals of fire. Some types of confectionery are traditional menus, which are usually used as complimentary food, in the customs activities of the local community. This nutrient potential must be managed in the right way so that it can develop socio-economic and family health. The number of nutritional adequacy in each type of food consumed in the family depends on the method of selecting foodstuffs and processing techniques into healthy and balanced nutritionally balanced foods (Wiyono, 2016).

Furthermore, respondents who have received basic health services are encouraged to carry out follow-up services at the Sampara Community Health Center, or the health center closest to where they live if they experience health problems that might interfere with their daily activities. This has been coordinated with the head of the Sampara Public Health Centre, and health workers.

\section{CONCLUSIONS}

Organizing information on the management of pokea clam meat, and examining the nutritional status of the community, is expected to increase the knowledge, attitudes, and behavior of the community in maintaining personal health and environmental health, so as to prevent the occurrence of diseases that they experience.

Counseling and basic health services for the poor who have been implemented in Andelapi Village, Sampara District, Konawe Regency, can be carried out well and smoothly, thanks to the collaboration of the FK UHO lecturers' team, along with the participation of various parties including the Research and Community Service Institution (UPM LPPM), village officials and Sampara Public Health Centre officers. 
Given the limited time and reach of health services for all disadvantaged communities, it is necessary to have more sustainable service cooperation, especially for the target of disadvantaged communities, because the background of environmental conditions and socio-economic conditions are still lacking.

\section{ACKNOWLEDGMENTS}

This community service is funded through the DIPA of the University of Halu Oleo (UHO) Fiscal Year 2018, with a Letter of Agreement for the Implementation of Activities Number: 3887/UN29.2.1/KU/2018.

Thank you to the UHO Institute for Research and Community Service (LPPM), the entire dedicated team, UHO Medical Faculty students, respondents, village heads and Public Health Centre heads, for all their cooperation

\section{REFERENCES}

Bahtiar, Hamzah,.dan Hari, H. (2015). Studi Struktur dan Pertumbuhan Populasi Kerang Pokea (Batissaviolacea var. celebensis, von Martens 1897) di Sungai Pohara Sulawesi Tenggara, Jurnal Biologi Tropis, 15(2): 110-120.

Dinkes Sultra. (2018). Profil Kesehatan Sulawesi Tenggara Tahun 2017. Dinas Kesehatan $\begin{array}{llll}\text { Provinsi } & \text { Sulawesi } & \text { Tenggara. } & \text { Retrieved }\end{array}$ http://www.depkes.go.id/resources/download/profil/PROFIL_KES_PROVINSI_2 017/28_Sultra_2017.pdf 
Kemenkes RI. (2014). Pedoman Gizi Seimbang (Pedoman Teknis Bagi Petugas Dalam Memberikan Peyuluhan Gixi Seimbang). Direktur Jenderal Bina Gizi dan KIA. Jakarta: Kementerian Kesehatan Republik Indonesia.

Kemenkes, 2019. Profil Kesehatan Indonesia Tahun 2018. Pusat Data dan Informasi $\begin{array}{llll}\text { Kementrian } & \text { Kesehatan } & \text { RI. } & \text { Retrieved }\end{array}$ http://www.depkes.go.id/resources/download/pusdatin/profil-kesehatanindonesia/Data-dan-Informasi_Profil-Kesehatan-Indonesia-2018.pdf

Notoatmodjo, S. (2011). Kesehatan Masyarakat, Ilmu dan Seni. Jakarta: Rhineka Cipta.

Biro Pusat Statisti. (2017). Kecamatan Sampara Dalam Angka. Retrieved at https://konawekab.bps.go.id/publication/2017/09/19/0f87a6f820687340fbc42110/ kecamatan-sampara-dalam-angka-2017.html

Supariasa, D.N., Bakri, B., dan Fajar, I. (2017). Penilaian Status Gizi. Editor: Etika Rezkina, Cahya Ayu Agitin, Jakarta: EGC.

Wiyono, S. (2016). Angka Kecukupan Gizi dan Survey Konsumsi, dalam Buku Ajar Epidemiologi Gizi, Konsep dan Aplikasi. Jakarta: CV Sagung Seto.

Yenni. (2012). Pengaruh Perebusan Terhadap Kandungan Gizi Kerang Pokea (Batissa violacea celebensis Marten 1897) dan Aktivitas Antioksidannya. Bogor: IPB.

Yenni, Tati N., Nurjanah, dan Fitje L. (2011). Kandungan Mineral, Proksimat dan Penanganan Kerang Pokea (Batissa violacea celebensis von Marten 1897) dari Sungai Pohara Sulawesi Tenggara. [Prosiding] Pertemuan Ilmiah dan Seminar Nasional MPHPI 2011. 
Yenni, Tati N., dan Nurjanah. (2012). Pengaruh Perebusan Terhadap Kandungan Asam Lemak Dan Kolesterol Kerang Pokea (Batissa violacea celebensis Marten 1897). JPHPI, 15 (3). 


\section{APPENDIX}

Table 3. Characteristics of Pokea Clam Meat Consumption Pattern

Description of the Questions for the Pokea Clam Consumption Pattern Yes No

$(n=72)$

(\%) (\%)

\section{A. Consumption Frequent}

1. How many times have you consumed pokea clam meat in a day?
a. 1-3 times/day
$58 \quad 42$
b. $>3$ times/day
$6 \quad 94$

B. Amount Consumption (Portion)

2. How many pokea clam are consumed, one meal?
a. <1/2 glass
$4 \quad 96$
b. $1 / 2-1$ glass
$57 \quad 43$
c. > 1 glass
$24 \quad 76$

\section{How to process}

3. How do you process the Pokea clam meat?
a. Boiled
$\begin{array}{ll}69 & 31\end{array}$
b. Fried
$43 \quad 57$
c. Burnt
$8 \quad 92$
d. Pan-fried
$33 \quad 67$
e. Baked
$7 \quad 93$

\section{Processed Types}

4. What kind of processed pokea clam do you consume?
a. Satay pokea
$39 \quad 61$
b. Saute pokea
199
c. Boiled Pokea
$8 \quad 92$
d. Fried Pokea

$1 \quad 99$

\section{E. Types of Component Foods}

$\begin{array}{lll}\text { 5. Do you consume White Rice with Pokea clam meat? } & 81 & 19\end{array}$

6. Do you consume Buras with processed pokea clam meat? $\quad 18 \quad 82$

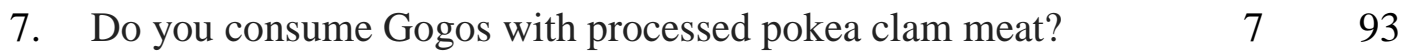

Source : Primary Data (2018) 